\title{
Giovanni Mafera, Carla Avanza Juul Madsen og Henning Juul Madsen: Gyldendals røde ordbøger Dansk-Italiensk. Gyldendal, 1993
}

Nærværende ordbog er et længe savnet bidrag til rækken af røde ordbøger og er som sådan en bilingval sprogordbog. For at anskueliggøre ventetiden kan det nævnes at 2. udgave af Gyldendals røde italiensk-dansk af samme forfattere udkom i 1980, og at dette er den første større dansk-italienske ordbog siden Berlingske Forlags fra 1959, som sidst er revideret grundigt i 1968 (Høybye og Mengel, 1968) og senere overtaget af Munksgaard, som siden har udgivet den uden væsentlige ændringer.

Ordbogen består af et dansk forord $(1 / 2$ side), et italiensk forord $(1 / 2$ side $)$, et afsnit om ordbogens anvendelse ( $41 / 2$ side), forkortelsesliste ( 3 sider), den alfabetiske ordliste (762 sider), to lister over uregelmæssige eller svære verber i hhv. italiensk ( 11 sider) og dansk $\left(2 \frac{1}{2} 2\right.$ side) og disses bøjning.

Forordet omtaler nødvendigheden af opofrelser fra forlag og forfatteres side p.g.a. det lille marked for en sådan ordbog, hvilket formentlig skal tolkes derhen at forfatterne i høj grad har arbejdet gratis, og forlaget er i tvivl om, hvorvidt trykkeomkostningerne kan dækkes. I betragtning af at der altså er tale om et con amore-projekt må man sige at der er gjort et ganske godt stykke arbejde, og det kan derfor synes urimeligt at gå så meget i detaljer som det er tilfældet i det følgende. Lad det derfor være sagt med det samme: Denne anmeldelse bør betragtes som en udpegning af områder, der bør opprioriteres ved fremtidige udgaver, snarere end som en kritik af det store arbejde, der vitterligt er gjort fra forfatternes side.

Ordbogens målgruppe er uafgrænset bortset fra nationalitet: Af det italienske forord fremgår det, at den primært henvender sig til danskere, men kan anvendes passivt af italienere (til oversættelse fra dansk eller ved læsning af danske tekster). Af hensyn til de italienske brugere er der medtaget oplysninger om visse danske verbers former samt nogle semantiske oplysninger, der er overflødige for danske brugere. Man kan således udlede, at ordbogen primært er beregnet til anvendelse ved oversættelse til italiensk, altså som aktiv ordbog.

Den dækker primært alment sprog, men der er taget ganske mange fagudtryk fra mange områder med. Fagudtrykkene er desværre ret tilfældigt udvalgt, således findes bremsetromle som opslagsord, men bremseskive, som idag er det mest udbredte, må udledes af skivebremse; et generelt begreb som notarialdokument findes (med en ukorrekt ækvivalent: strumento, burde være rògito som angivet for notarialakt) men ikke det mere specifikke notartestamente, som flere måske kan have brug for at slå op.

Ordbogsdelen indeholder ca. 60.000 opslagsord, og (ifølge en folder fra 
Gyldendal om forlagets ordbøger) 25.000 udtryk og vendinger. Denne del af bogen er sat i tre spalter med læsevenlige typer, opslagsordene er med fed skrift, målsprogsækvivalenter med almindelige typer, og flerordsforbindelser, eksempler og bemærkninger med kursiv. Bemærkninger er desuden adskilt fra resten af teksten med parenteser, men det ville lette læsningen, hvis de var markeret med en anden skrifttype.

Grundlaget for ordbogen er ikke oplyst. Så vidt jeg ved har forfatterne haft "vendt" materiale fra den røde italiensk-danske ordbog til rådighed, men de har stort set undgået at misbruge det. Jeg har kun fundet ganske enkeltstående eksempler hvor det er gået galt. Således findes tændingsanordning som opslagsord, skønt man ikke kan sige at det er et fast udtryk. Det er oversat til spinterògeno, og et opslag under dette i den italiensk-danske ordbog giver netop tændingsanordning. Men spinterogeno betyder strømfordeler, dette ord har i ordbogen fået den mere direkte oversættelse distributore [d'accensione]. Det andet eksempel jeg har fundet er opslagsordet benbygning, et ord jeg ikke umiddelbart lægger noget i (bygning til/af ben?), med oversættelsen ossatura og et 'tilbageopslag' giver igen benbygning. Ossatura betyder faktisk knoglebygning eller skelet (også overført om f.eks. bygninger og skibe), men hverken knoglebygning eller skelet findes som opslagsord.

Det oplyses ikke hvilke kriterier, der ligger til grund for udvælgelsen af lemmaer, dog anføres det i vejledningen at 'de almindeligere ord, der nu må anses for forældede', er medtaget hvis de forekommer i litteraturen efter ca. 1870 (Italiens samling), men det oplyses ikke, om det gælder både danske og italienske ord, eller hvorvidt ord i denne kategori er markeret i ordbogen. Iøvrigt er ikke alle ord oversat med deres nyeste ækvivalent, f.eks. oversættes forældremyndighed til patria potestá, et udtryk, der kun går på faderen, og som idag er erstattet af potestá dei genitori, der går på begge forældre.

Der er også medtaget en del sjældne ord, som end ikke findes i Bergenholtz' Frekvensordbog (Bergenholtz, 1992), bl.a. jøkel, der bruges om norske og islandske gletschere og nappetag (at tage et nappetag = at nappes, at småskændes). I andre tilfælde er det den mest perifere betydning af et ord der er valgt, det gælder f.eks. afbræk der kun har ækvivalenter til betydningen 'skade', mens den langt almindeligere 'tidsmæssig afbrydelse' slet ikke er med.

Til gengæld er der mange forkortelser, og de får en udmærket behandling: det oplyses hvad de står får, så følger den tilsvarende italienske forkortelse samt hvad den står for. Også geografiske navne er med, hvilket er en stor fordel, da de italienske former i almindelighed foretrækkes. Endelig er personnavne (fornavne) medtaget i ordbogen, hvilket er knap så nødvendigt; ganske vist har historiske personers navne oftest fået en italiensk ækvivalent, men navne oversættes ikke generelt. 
Opslagsordene er ordnet alfabetisk med nicher, således at f.eks. artiklen med sammensætninger med dør- afbrydes mellem -håndtag og -karm for at give plads for en artikel (niche) til dørk. Homografer har hver sin artikel, og er markeret med et nummer i høj skrift.

Hvor retskrivningsordbogen tillader flere stavemåder er der fulgt forskellige fremgangsmåder. I enkelte tilfælde er der to fulde artikler med betydningsækvivalenter f.eks. Schweiz / Svejts. I andre tilfælde rummer den ene artikel alene opslagsordet og en henvisning til den anden stavemåde: hefte d.s.s. haefte, trevl d.s.s. travl, kikke d.s.s. kigge. Endelig er der en del tilfælde hvor begge stavemåder er anført i den samme artikel - i disse tilfælde kan man kun slå op på den ene stavemåde, hvilket kan være et problem især for italienske brugere: nopret ( $e l$. nubret), plire ( $e l$. plirre), tredive ( $e l$. tredve), pønse ( $e l$. pфnske) - at pфnske ikke er med fed skrift som de øvrige alternativer må betragtes som en trykfejl. Nogle stavemåder findes slet ikke, det gælder f.eks. majonæse (kun mayonnaise), krem (kun creme), paj (kun pie), linje (kun linie) igen især problematisk for italienske brugere.

Der angives i de fleste tilfælde flere italienske ækvivalenter til et givet opslagsord. De er ofte adskilt v.hj.a. betydningsangivelser eller forklaringer af forskellig art, men de forskellige betydninger er desværre ikke ordnet systematisk, jvf. nedenfor om flerordsforbindelser. Hvor det ikke har været muligt at finde en fuldstændig ækvivalent kan det være markeret med forkortelsen omtr. (omtrent/kan gengives ved). I mange tilfælde er der dog snarere tale om forklaringer end oversættelsesækvivalenter, f.eks. er gløgg, oversat til opskriften 'vino caldo con uva passa, mandorle e spezie', eller dagpenge, der forklares med 'somma corrisposta al lavoratore in risarcimento di un giorno di lavoro perduto'. At der er tale om en forklaring er ikke altid markeret med omtr. eller andet der kan fortælle en dansk bruger, at han/hun skal være på vagt, det gælder f.eks. dagplejemor der forklares som 'bambinaia stipendiata dal comune'. I Høybye og Mengels ordbog finder man ækvivalenter, ikke forklaringer - til gengæld mangler en del af de vanskeligt oversættelige ord. Forklaringerne kunne formentlig i højere grad have været undgået, hvis man var gået systematisk til værks - d.v.s. havde taget et emneområde ad gangen - istedet for alfabetisk.

Der er ikke angivet udtale for danske ord, hvilket er i overensstemmelse med at ordbogens primære målgruppe er danskere. Forholdet mellem ortografi og udtale på italiensk er enkelt, der er kun tre kritiske punkter: placering af tryk, kvaliteten af e og o i trykstærk stavelse (åben/lukket udtale) og hvorvidt intervokalisk s og z skal være stemt eller ej. Trykket falder normalt på næstsidste stavelse, falder det på sidste stavelse er det ifølge italiensk retskrivning markeret med accent. De ord, der har tryk på trediesidste stavelse er her i ordbogen (i overensstemmelse med gængs praksis) markeret med en accent, som 
altså ikke hører med til italiensk retskrivning. Dette er der gjort rede for i 'vejledning i bogens brug'. Vokalkvaliteten er markeret med hhv. accent aigu (åben) og accent grave (lukket) - men kun i de tilfælde, hvor der i forvejen er en accent. D.v.s. at vokalkvaliteten ikke er angivet ved alle de ord, hvor trykket falder på næstsidste stavelse. Som begrundelse herfor anføres i vejledningen at udtalen varierer blandt italienere, men det er jo også tilfældet i sidste og trediesidste stavelse, hvor vokalkvaliteten er markeret. Iøvrigt henvises der til italiensk-dansk ordbog (Gyldendals røde), hvor der er sat ekstra accenter (aigu/grave) over næstsidste stavelse med e eller o, eller ensprogede italienske ordbøger. Stemthed af s og z nævnes overhovedet ikke og er ikke markeret (også her varierer udtalen blandt italienere). Til sammenligning kan nævnes at det er angivet med prik over bogstavet i italiensk-dansk ordbog. I Høybye og Mengel (1968) er udtale slet ikke angivet. Da ordbogen er beregnet for danskere burde både vokalkvalitet og stemthed for rigssproget (eller en angivet variant) være anført.

Opslagsordenes ordklasse er markeret med en forkortelse efter ordet, ved substantiver dog ved at bøjningsendelserne er angivet (ved sammensatte ord må bøjningen søges ved at slå sidste led op). Særligt af hensyn til italienske brugere er stærke og uregelmæssige verbers bøjning angivet.

For italienske substantiver er genus markeret, hvor dette ikke kan udledes af endelsen (der gives en udførlig forklaring i vejledningen) og bøjning er angivet hvor den danske ækvivalent er ens i ental og flertal, f.eks. dyr - et, - animale/i - egentlig overflødigt, da det italienske ord er regelmæssigt, men pædagogisk godt, som en påmindelse til den danske bruger: husk at bøje! Desuden er det markeret med $s g$. eller $p l$. hvis den korrekte oversættelse af det danske udtryk skal være hhv. ental eller flertal, f.eks. saks -en, -e fòrbici f.pl. Verbers bøjning er ikke angivet, det italienske verbalparadigme er for stort til at kunne anføres hver gang et verbum indgår i en ækvivalent, men en lille markering, f.eks. *, kunne være på sin plads ved de verber, der er med på listen bag $\mathrm{i}$ bogen. At listen er der, er iøvrigt et fremskridt i forhold til Høybye og Mengel (1968), som helt undlader at give oplysninger om verbers bøjning.

De grammatiske oplysninger kunne i det hele taget godt være mere grundige. F.eks. findes på italiensk et antal hankønsord, der har to flertalsformer med forskellig betydning, en regelmæssig på -i (med distributiv betydning) og en uregelmæssig med genusskift på -a, med kollektiv eller par- betydning. En undergruppe er betegnelser på en række legemsdele, som f.eks. braccio (arm), der i den uregelmæssige flertalsform betegner et menneskes to arme, mens det i den regelmæssige flertalsform betegner et antal arme, f.eks. på en lysestage. Det er i ordbogen kun angivet ved to af disse at de har to flertalsformer: budello (tarm); ginocchio (knæ), og kun ved det ene (budello) er betydningsforskellen forklaret. Ved to af de øvrige, labbra (læbe); osso (knogle) er angivet fler- 
talsformen på -a (men ikke den på -i), med osso skal man imidlertid være opmærksom på at le ossa betegner et skelet (der, som nævnt, iøvrigt ikke findes som opslagsord), mens gli ossi er en tilfældig benbunke - det er ikke anført. Ved de øvrige fire (braccio (arm); (sopra) ciglio (bryn, øjenbryn), corno (horn) og dito (finger) kan formen på -a ses i eksemplerne, men forskellen på de to anvendelser kan kun udledes hvis man ved, hvad man leder efter. Ved andre ord af denne type er begge former angivet i ca. halvdelen af tilfældene. Forskellen giver anledning til forskellige oversættelser, og burde derfor have været angivet $\mathrm{i}$ alle tilfælde.

Da ordbogen er beregnet til aktiv sprogbrug bør den også indeholde konstruktionsoplysninger. En helt basal oplysning er verbers valens som bør angives i en lettilgængelig og overskuelig form, f.eks. som sætningsmønstre. Desværre er der her ikke brugt en systematisk fremgangsmåde. I visse tilfælde finder man én/noget (forkortet til én/ngt) oversat til qualcuno/qualcosa (forkortet til q/qc), f.eks. lokke (...) lokke ngt fra én - ottenere qc. da q.; støde (...) urtare (til én/ngt contro q/qc). I andre tilfælde er der givet nogle mere tilfældige eksempler på udfyldning, under støtte finder man f.eks. efter nogle faste forbindelser som stфtte på benene og støtte hovedet $i$ handerne eksemplet sygeplejersken støttede patienten. Generelt gives der ofte unødvendigt lange eksempler og de er iøvrigt blandet med faste forbindelser, så man ikke umiddelbart kan skelne mellem rene eksempler, hvor alle andre ord end opslagsordet lader sig udskifte, helt faste forbindelser, og blandingstilfælde. F.eks. finder man under stå eksemplet det regner så det står efter som eneste eksempel på brugen af så det står efter. Den italienske bruger kan heraf fejlagtigt udlede at man kun kan bruge denne konstruktion i forbindelse med (regn)vejr, og den danske bruger kan omvendt tro at den italienske ækvivalent har denne begrænsning. Tilsvarende med stå for en fest - essere l'organizzatore di una festa, her ville man være bedre hjulpet med stå for (et arrangement) - essere l'organizzatore di (una manifestazione). Markering med parenteser af udskiftelige dele af eksemplerne ville i det hele taget være en stor hjælp.

Flerordsforbindelser (herunder eksempler) er opført i kursiv med tilde, og der er lagt en stor grundighed for dagen hvad angår mængden af udtryk og vendinger med de enkelte opslagsord, men der kunne have været gjort mere ud af at systematisere dem. I større artikler kommer der først et antal flerordsforbindelser i tilfældig rækkefølge, hvorefter resten af artiklen er opdelt efter hvilke andre ord (skrevet med fed skrift) der indgår i forbindelsen. Ved verbet gå (ialt $5^{1} \frac{1}{2}$ spalte) angives således først italienske ækvivalenter til nogle semantiske undergrupper (på sine ben, om tid, trakke sig tilbage), næste del af artiklen viser sig ved gennemlæsning hovedsageligt at rumme eksempler på forskellige typer af subjekter, som giver forskellig oversættelse af gå (tog, vare, ur, dør, snakken, regeringen). Derefter følger en række forbindelser 'med adv., pron. 
etc.' (bl.a. blive gået!!) og tilsidst en gruppe 'med prap. og adv.' Desværre forekommer det ikke sjældent, at nogle forbindelser med præpositioner står i den første uorganiserede del af artiklen, så man på trods af inddelingen kan være nødt til at læse hele artiklen igennem i sin søgen efter et udtryk. Gå bort i betydningen 'gå et andet sted hen' står således både i afdelingen med forskellige subjekter (i imperativ) og i gruppen med prap. og adv., mens betydningen ' $\mathrm{d} \varnothing$ ' kun findes i sidstnævnte gruppe. Efter verbet høre finder man grupper af forbindelser med ad, efter, for, hen, hjemme, ind, med, om, op, på, sammen, til og under, men flg. forbindelser findes i første del af artiklen, sammen med en del andre uden præp/adv: det er laenge siden jeg har hørt fra ham; nu har jeg hørt det med; lade fra sig; lade én om ngt.; lade én for en forseelse. Placeringen af en forbindelse under et givet opslagsord er noget tilfældig, således findes glædelig jul under glædelig, mens godt nytår er opført under nytår. Generelt er der ikke henvisninger fra en artikel til flerordsforbindelser hvori opslagsordet indgår i en anden artikel, man må prøve sig frem. Fra alle månedsnavne henvises dog til april, hvor man finder oplysning om konstruktion af datoer og udtryk som 'april måned'. I nogle tilfælde er anført ukorrekte danske vendinger, f.eks. findes lagge fingrene imellem for én (men ikke det korrekte lagge fingrene imellem), eller der er opført en sjælden variant frem for den almindelige: have noget på hjertet (som Ordbog over det danske sprog oplyser er en lidet brugt variant af have noget på hjerte).

Udover det rent konstruktionsmæssige har man ofte brug for mere pragmatiske sprogbrugsoplysninger, og sådanne er da også medtaget i denne ordbog. På grundlag af forkortelseslisten kan man se at der er taget højde for geografisk varians, idet der er anført forkortelser for nord-, syd- og mellemitaliensk, romersk, toscansk og venetiansk. Det er klart at en ordbog af denne størrelse ikke kan medtage alle mulige lokale varianter, men der kan være mening i at medtage nogle fra udvalgte områder. Det gælder f.eks. romersk, da Rom som bekendt er hovedstad, og romerske udtryk derfor har en vis udbredelse i medierne. Da italiensk rigssprog har sine rødder i toscansk, kan det også være udmærket at angive særlige toscanismer, som ikke hører til rigssproget, men at særlige venetianske udtryk er taget med i ordbogen frem for andre regionale varianter kan nok kun forklares med en af redaktørernes herkomst.

M.h.t. tidsmæssigt varians bruges betegnelsen 'gammeldags', men der er ikke gjort rede for efter hvilke kriterier den anvendes.

Derudover er brugt en række angivelser for fagområder, f.eks. anatomisk, botanisk, teknik, telekommunikation, jura. De bruges dog ikke helt konsekvent, f.eks. er notarialdokument markeret med 'jura', men ikke notarialakt.

Der bruges også en række stilmarkører ('poetisk sprog','litterært', 'højere stil', 'bureaukratisk', 'skriftsprog', 'talesprog/uformelt skriftsprog', 'slang' og 
'vulgært'), som umiddelbart kan forekomme nyttige, men er svære at bruge i praksis. Betyder 'poetisk sprog' eller 'litterært' at det pågældende udtryk KUN bruges her? Hvem afgør, om en given vending er 'vulgær' eller om en anden er 'højere stil', og hvor går grænsen mellem 'vulgær', 'slang' og 'talesprog'? Ordet nosse, som jeg mener hører til talesprog, har således fået betegnelsen 'vulgært', mens ækvivalenten - coglione - er umarkeret (men vulgært/slang i den italiensk-danske ordbog). Til gengæld er brunstig brugt om mennesker umarkeret - personligt ville jeg nu ikke bruge udtrykket ret mange steder. Endelig er det italienske 'scoreggiare', der er umarkeret ved opslag under prutte, markeret som 'vulgært' når man slår op under fjærte. En markering af at et udtryk udelukkende hører til 'skriftsprog' eller 'talesprog/uformelt skriftsprog' er dog absolut ønskværdig, ligesom betegnelserne 'nedsættende', 'ironisk' og 'spøgende', i det omfang de bruges konsekvent.

Man savner ofte vejledning i brugen af mere almindelige udtryk, f.eks. ville det under goddag være rart med en oplysning om at man efter kl.14 ikke længere siger 'buon giorno' men 'buona sera' (egentlig godaften), og under du kunne det være angivet at det er mindre udbredt $i$ Italien. Til gengæld forklares det ofte ved mere specielle begreber om et udtryk kun gælder danske hhv. italienske forhold, og disse betegnelser bruges generelt godt, evt. i kombination med 'omtrent/kan gengives ved'. Kriminalpoliti kan således omtrent oversættes til 'polizìa giudiziaria' eller 'squadra mobile', men er talen om italienske forhold kan også 'carabinieri' bruges. Landsting oversættes til 'parlamento della Groenlandia', men det oplyses også at det brugt om danske forhold 18491953 hedder 'senato'. Sådanne oplysninger mangler helt i Høybye og Mengel (1968).

Sammenfattende må man konstatere at ordbogens største svaghed ligger i den manglende systematik på alle planer. Der er gjort en del ud af at finde oversættelser, men ofte er der givet forklaringer istedet - formentlig fordi det har været et hobbyarbejde snarere end hovedbeskæftigelse. Disse indvendinger gælder dog også mange andre tosprogede ordbøger, der må bruges med nogen varsomhed. Generelt kunne man ønske sig at forlagene ville være lidt mere opofrende, og aflønnede leksikografer ordentligt, så det blev muligt at lave mere professionelt ordbogsarbejde.

På trods af de ovenfor anførte kritikpunkter er der dog tale om et stort fremskridt for alle der beskæftiger sig med italiensk - man vil med denne ordbog være bedre i stand til at finde korrekte oversættelser, end det har været muligt tidligere, og jeg kan kun anbefale italianister at have den røde dansk-italienske stående inden for rækkevidde på boghylden. 


\section{Referencer:}

Bergenholtz, H. (1992): Dansk frekvensordbog, Gad, København.

Dahlerup, V (1919-1956): Ordbog over det danske sprog, København.

Høybye, P. og J. Mengel (1968): Dansk-italiensk ordbog, Berlingske ordbøger, København.

Hanne Erdman Thomsen 